\title{
Inheritance of Powdery Mildew Resistance in Sweet Cherry
}

\author{
James W. Olmstead and Gregory A. Lang ${ }^{1}$ \\ Department of Horticulture, Plant and Soil Sciences Building, Michigan \\ State University, East Lansing, MI 48824-1325
}

\section{Gary G. Grove \\ Irrigated Agriculture Research and Extension Center, Washington State University, 24106 North Bunn Road, Prosser, WA 99350-9687}

Additional index words. disease resistance, Prunus avium, Podosphaera clandestina, genetics, monogenic, foliar immunity, integrated fruit production

\begin{abstract}
Most sweet cherry (Prunus avium L.) cultivars grown commercially in the Pacific Northwestern states of the United States are susceptible to powdery mildew, caused by the fungus Podosphaera clandestina (Wall.:Fr.) Lev. The disease is prevalent in the irrigated arid region east of the Cascade Mountains in Washington State. Little is known about genetic resistance to powdery mildew in sweet cherry, although a selection (PMR-1) was identified at Washington State Univ.'s Irrigated Agriculture Research and Extension Center that exhibits apparent foliar immunity to the disease. The objective of this research was to determine the inheritance of powdery mildew resistance from PMR-1. Reciprocal crosses were made between PMR-1 and three highquality, widely-grown susceptible cultivars ('Bing', 'Rainier', and 'Van'). Resultant progenies were screened for reaction to powdery mildew colonization using a laboratory leaf disk assay. Assay results were verified by natural spread of powdery mildew among the progeny in a greenhouse and later by placing them among infected trees in a cherry orchard. Segregation within the progenies for powdery mildew reaction fit a 1 resistant : 1 susceptible segregation ratio $(P \leq 0.05)$, indicating that resistance to powdery mildew derived from PMR-1 was conferred by a single gene.
\end{abstract}

Powdery mildew of sweet cherry is common in the irrigated orchards of eastern Washington State. Although yield losses have not been estimated, powdery mildew is considered the most serious preharvest disease of sweet cherries in this region (Grove, 1991, 1998; Grove and Boal, 1991a, 1991b), which is a world leader in fresh-market cherry exports. Among three of the leading cultivars produced, 'Bing' is highly susceptible, and 'Van' and 'Rainier' moderately susceptible, to $P$. clandestina (Olmstead et al., 2000a), which routinely infects foliage during fruit development. Subsequently, fruit infections may appear in orchards with high incidence and severity of foliar powdery mildew (Grove and Boal, 1991b). Fruit infections reduce fruit quality, and profit potential is lost when

Received for publication 15 May 2000. Accepted for publication 6 Sept. 2000. This paper is a portion of a thesis submitted by J.W.O. in partial fulfillment of requirements for the MS degree at Washington State Univ. We thank W.E. Howell and D. Pehrson for allowing use of field plots and trees, and P. Miklas for providing additional growth chamber space. We also gratefully acknowledge the financial support of the Washington State Univ. College of Agriculture and Home Economics and the Washington Tree Fruit Research Commission. The cost of publishing this paper was defrayed in part by the payment of page charges. Under postal regulations, this paper therefore must be hereby marked advertisement solely to indicate this fact. ${ }^{1}$ To whom requests for reprints should be addressed. E-mail address: langg@msu.edu entire lots of fruit are rejected with incidences as low as 5\% (Grove, 1991).

Podosphaera clandestina overwinters in the sexual stage as cleistothecia, which serve as the primary source of inoculum (Grove and Boal, 1991a). Seasonally, powdery mildew is first observed as light-colored lesions on young leaves in the inner portions of the tree canopy. As disease severity increases, blistering and leaf deformation occur, corresponding with rapid increases in secondary inoculum (i.e., conidia of the pathogen). Current regulations prohibit growers from applying fungicides immediately before and during harvest, thus increasing the potential for severe infection after harvest (Grove, 1998).

Presently, powdery mildew is controlled by multiple applications of demethylationinhibiting (DMI) fungicides. Repeated use of similar fungicides has led to the development of site-specific incidences of $P$. clandestina resistance to members of this class of fungicides (Grove, 1997). Grape (Vitis sp.) powdery mildew [Uncinula necator (Schwein.) Burrill] has a similar life cycle, and this pathogen also has developed resistance to some of these commonly used fungicides (Erickson and Wilcox, 1997; Gubler et al., 1996).

The development of fungal resistance to primary chemical control tactics, coupled with the increasing interest of growers and consumers in reducing chemical inputs during production, led to the initiation of a project at Washington State Univ.'s Irrigated Agri- culture Research and Extension Center (IAREC) to identify and develop powdery mildew-resistant sweet cherry cultivars for commercial production (Olmstead et al., 2000b). Previously, powdery mildew resistance in sweet cherries received little attention compared to other important tree fruit crops for which this disease is problematic, such as peach [Prunus persica (L.) Batsch] (Dirlewanger et al., 1996) and apple (Malus sp.) (Dayton, 1977; Gallott et al., 1985; Janse et al., 1994; Korban and Dayton, 1983). Variation in susceptibility to powdery mildew exists among cherry cultivars and related species; Hedrick (1915) described $P$. avium and $P$. cerasus L. (sour cherry) as mildew-susceptible, while mildew symptoms were rarely observed on $P$. mahaleb L. Based on field observations, English (1947) concluded that 'Lambert' and 'Napoleon' were less susceptible than 'Bing', and infected fruit were found on 'Bing', 'Black Tartarian', and 'Lambert', but not 'Napoleon'. Only 'Hoy' and 'Wood' showed no powdery mildew infection (Hedrick, 1915; Hesler and Whetzel, 1937). More recently, distinct differences in susceptibility to powdery mildew were detected among 14 sweet cherry cultivars (Olmstead et al., 2000a).

Despite this variability in susceptibility among sweet cherry cultivars, the mode of inheritance of resistance has not been determined. Following greenhouse observation at IAREC, the selection PMR-1 was identified in 1977 as immune to powdery mildew (Toyama et al., 1993). No pedigree information is available, as PMR-1 originated from a group of open-pollinated seedlings ( $\mathrm{T}$. Toyama, personal communication). Subsequent study confirmed that PMR-1 is immune to foliar infection and colonization by $P$. clandestina, although the physiological mechanism of resistance is not known (Toyama et al., 1993). The fruit quality of PMR-1 is slightly lower than that of existing cultivars, limiting its potential for commercial production. However, preliminary observations (1996-97) of open-pollinated progeny from PMR-1 suggested segregation for powdery mildew resistance (J.W. Olmstead and G.A. Lang, personal observation), suggesting that the resistance trait may be useful in sweet cherry breeding.

The objective of this study was to determine the inheritance of powdery mildew resistance derived from PMR-1 among individuals within $F_{1}$ progenies generated from reciprocal crosses of PMR-1 and three susceptible sweet cherry cultivars.

\section{Materials and Methods}

Plant materials and population development. Reciprocal crosses were made in Apr. 1998 between PMR-1 and three widelygrown susceptible cultivars ('Bing', 'Rainier', and 'Van'). Pollen was collected from each of the four cultivars $\approx 2$ weeks prior to natural anthesis by forcing flowers on cut shoots in the laboratory (Fogle, 1975). Pollen was stored at $0{ }^{\circ} \mathrm{C}$ prior to use. Crosses using PMR-1 as 
the maternal parent were made at the Washington State Univ. (WSU) Roza Experimental Orchards near Prosser, Wash., while reciprocal crosses were made at the WSU Tukey Orchard near Pullman, Wash., where trees bloomed $\approx 2$ weeks later than at Prosser.

Flowers were emasculated by hand immediately prior to controlled pollination. To obtain segregating progenies of $\approx 100$ individuals for each reciprocal cross, it was estimated that 2000 hand pollinations per cross should be conducted to account for the low seed-set and low seedling germination associated with artificial sweet cherry pollination (Toyama, 1978). Given the limited availability of viable flowers, only 1000 hand pollinations were made for each reciprocal cross with 'Van'. Limbs with pollinated flowers were protected from insect pollination and bird damage by cages covered with cheesecloth. Fruit were picked at full maturity (July 1998), and pits were immediately extracted. Pits were cleaned thoroughly, surface-disinfested for $1 \mathrm{~min}$ in $0.5 \%$ sodium hypochlorite, and allowed to soak in sterile distilled water for $24 \mathrm{~h}$. After soaking, the endocarps were cracked (Fogle, 1975), and groups of 25 seeds from each cross were placed in polyethylene bags containing $\approx 700$ $\mathrm{g}$ of moist, sterile sand mixed with $5 \mathrm{~g}$ of powder fungicide (Ferbam; FMC Corp., Philadelphia). Bags of seed were stratified at $4{ }^{\circ} \mathrm{C}$ in the dark for 5 months (Galletta, 1983).

For most of the seeds, radical elongation began during stratification. After stratification, seeds were planted individually in 10$\mathrm{cm}^{2}$ (0.9-L) plastic pots containing a pasteurized greenhouse medium ( 3 peat moss : 2 vermiculite, by volume). All pots were moved to a greenhouse maintained at 20 to $25^{\circ} \mathrm{C}$. In May 1999, all seedlings were transplanted to 4.5-L pots using the greenhouse medium described previously. Seedlings were fertilized every 2 weeks with $15 \mathrm{~N}-13.1 \mathrm{P}-12.4 \mathrm{~K}$, (Miracle Gro ${ }^{\circledR}$; The Scotts Co., Marysville, Ohio) and watered as needed.

Leaf disk screening for powdery mildew resistance. To screen the populations for potential powdery mildew resistance while maintaining disease-free seedlings, a leaf disk assay was used as described previously (Olmstead et al., 2000a) with some modifications. Leaves were surface-disinfested in $70 \%$ ethanol for $30 \mathrm{~s}$ rather than $1 \mathrm{~min}$, and leaf disk size was reduced to $20 \mathrm{~mm}$ to conserve limited leaf tissue. Progeny from all reciprocal populations along with all four parents were randomized within the greenhouse. Leaf tissue from the first node of expanding shoots (emergent) was not available for leaf disk testing of all seedlings on the same date. Therefore, individual seedlings within each population were screened on different dates during the months of June through Aug. 1999.

Two controlled-environment growth chambers (Conviron CMP 3244; Conviron Products of America, Pembina, N. Dak., and Precision 818; Precision Scientific Group, Chicago), with temperature and photoperiod regimes as described previously (Olmstead et al., 2000a), were used for assay incubation.
Screening tests for leaf disks within the growth chamber were conducted as a randomized complete block, with three replications per seedling. Time and space limitations allowed only populations derived from 'Bing' and 'Rainier' to be screened using the leaf disk assay. Powdery mildew incidence and percentage of diseased area were assessed visually using a dissecting microscope (Bausch and Lomb, Rochester, N.Y.) at $\times 30$ and recorded $14 \mathrm{~d}$ after leaf disk inoculation (Olmstead et al., 2001).

Greenhouse screening for powdery mildew resistance. On 1 Aug. 1999, the first colonies of a natural powdery mildew outbreak were detected on several seedlings from each cross in the greenhouse. Under the optimized greenhouse conditions, the mildew spread rapidly. Disease incidence for each seedling within each population was scored visually as presence or absence of mildew symptoms (Olmstead et al., 2001) on 3 Aug. 1999.

Field screening for powdery mildew resistance. On 7 Aug. 1999, all potted seedlings assessed for powdery mildew incidence by the leaf disk assay were moved to a cherry orchard at the WSU Pear Acres field unit near Prosser, Wash. Seedlings were randomized by population within existing tree rows. To encourage natural mildew infection, the orchard received no fungicide applications during the 1998 or 1999 growing season. No measures had been taken to control the powdery mildew infection in the greenhouse. Therefore, all potted seedlings for field screening were inoculated naturally in the greenhouse and later were exposed to natural sources of inoculum in the orchard. Populations derived from 'Bing' and 'Rainier' were assessed for powdery mildew incidence on 7 and 9 Sept. 1999, respectively. The abaxial sides of 10 leaves were assessed visually for presence of powdery mildew colonies (Olmstead et al., 2001).

Determination of mode of inheritance. Chi square analysis (Steel and Torrie, 1980) was used to test the fit to expected segregation ratios and determine the inheritance of powdery mildew resistance in each of the populations for each of the three screening methods.

\section{Results and Discussion}

Plant materials and population development. Of the total controlled pollinations (i.e., 2000 for 'Bing' and 'Rainier' and 1000 for 'Van'), $\approx 5 \%$ to $10 \%$ produced viable seeds, except for the PMR-1 x 'Bing' hybridization, which produced only $2 \%$ viable seeds (Table 1). Although pollen viability tests (Galletta, 1983) were not performed on the fresh pollen collected for these crosses, low viability of the 'Bing' pollen is assumed to have contributed to this difference. Germination percentages for stratified seed were relatively high (T. Toyama, personal communication). Seed from reciprocal crosses of each susceptible parent had similar germination percentages ('Bing', 'Rainier', and 'Van' as the maternal or paternal parent were $61 \%$ and $60 \%, 74 \%$ and $75 \%$, and $68 \%$ and $73 \%$, respectively).

Albinism, a common seedling abnormality, was detected only in populations having 'Bing' or 'Van' as parents. Albinism is a single-gene recessive trait known to be heterozygous in 'Bing' (Fogle, 1961; Kerr, 1963). Fogle (1961) found no albinism among 'Bing' X 'Van' seedlings; however, a small percentage appeared in both reciprocal progenies using 'Van' in the present study, suggesting that PMR-1 and 'Van' are both heterozygous for the chlorophyll-deficiency allele. The small percentage of albino seedlings in these populations suggests that this trait may be lethal prior to seedling emergence, or other modifying genes are involved in inheritance of this trait (Fogle, 1961). The lack of albino seedlings in reciprocal progenies between PMR-1 and 'Rainier' suggests that 'Rainier' is homozygous dominant for albinism.

Screening progeny for powdery mildew resistance. Variation in leaf development across seedling populations required periodic screening to assure uniformity in leaf tissue assays. In each population, some individuals never produced adequate amounts of leaf tissue for evaluation. Hence, for the PMR-1 $x$ 'Bing' cross, $90 \%$ of the entire population was screened using the leaf disk assay, and for the 'Bing' x PMR-1, PMR-1 x 'Rainier', and 'Rainier' $x$ PMR-1 crosses, 92\%, 75\%, and $85 \%$ of the populations were screened, respectively (Table 1, leaf disk assay).

Mildew colonies were detected on susceptible plants in the greenhouse immediately prior to field screening, and this incidence under greenhouse conditions was recorded for those seedlings that had been screened in the leaf disk assay (Table 1, greenhouse incidence). These populations were then moved to an orchard for observation under natural disease conditions (Table 1 , field incidence). The only differences in disease scores for the three screening methods occurred in the greenhouse evaluation, where two individuals of the 'Rainier' populations appeared resistant, but were scored susceptible in both the leaf disk assay and field screening. Thus, the reliability of the leaf disk assay to predict orchard resistance or susceptibility was confirmed by both greenhouse and field screening results for the same individuals in each breeding population.

Inheritance of PMR-1 powdery mildew resistance. Segregation for powdery mildew resistance among progeny, within each reciprocal population for each screening method, fit a $1: 1(P=\approx 0.1$ to 0.95$)$ (Table 1$)$ segregation ratio, which indicates that resistance in PMR-1 is conferred by a single gene. All populations, except that from PMR-1 $x$ 'Bing', consisted of adequate numbers of individuals to discriminate between a $1: 1$ and 3:1 segregation ratio at $P \leq 0.05$ (Steel and Torrie, 1980). Segregation ratios for progeny from the PMR-1 x 'Bing' cross, with only 19 individuals tested (Table 1), fit both a $1: 1$ and $3: 1$ segregation ratio $(P=0.1$ to 0.25 , and 0.5 to 0.75 , respectively). 
Table 1. Segregation data, based on three different screening methods, for powdery mildew resistance among $\mathrm{F}_{1}$ sweet cherry progeny generated from crosses between PMR-1 (resistant) and 'Bing', 'Rainier', or 'Van' (all susceptible), tested to fit a 1:1 single-gene segregation ratio.

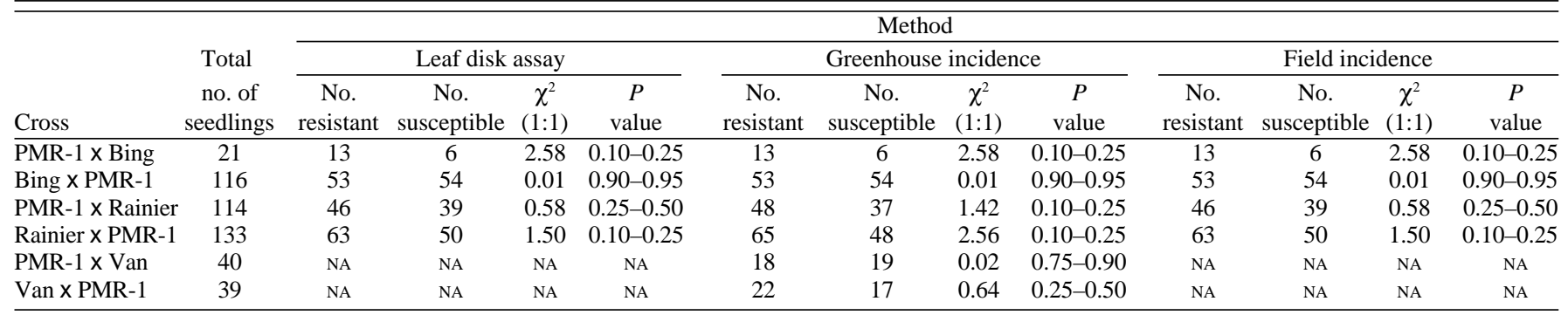

${ }^{\mathrm{NA} N o t}$ available.

Since no previous information concerning the inheritance of this gene has been reported, the allelic state at this locus for each parent used in these crosses cannot be determined from these data. PMR-1 could be homozygous recessive, or heterozygous for resistance, assuming a recessive or dominant gene model, respectively. Confirmation of either model will not be available for several years until further test crosses (Poehlman and Sleper, 1995) are conducted.

This is the first report of mode of inheritance of powdery mildew resistance in sweet cherry. The single-gene resistance will be relatively easy to introgress into new or existing selections. Although sweet cherries have a strong gametophytic self-incompatibility system, self-fertility has been induced through mutation breeding (Tehrani and Brown, 1992). Combining this trait with powdery mildew resistance will facilitate introgression of the resistance gene into existing cultivars by backcrossing. In addition to PMR1 , several other potential sources of qualitative powdery mildew resistance have been reported (Olmstead et al., 2000a); these may or may not carry the same resistance gene to $P$. clandestina as does PMR-1.

Inheritance of powdery mildew resistance in several other horticultural crops also has been reported to be monogenic. A single dominant gene conferring powdery mildew resistance in apple (Malus $\times$ domestica Borkh.) was identified in segregating progenies of mildew-immune selection (MIS) crossed with susceptible apple cultivars (Dayton, 1977) and confirmed with progeny tests (Korban and Dayton, 1983). Subsequently, single powdery mildew resistance genes were identified in segregating progenies from crosses between 'Golden Delicious' and [Morton Arboretum 8 (an interspecific hybrid of unknown parentage) and $M$. sargentii Rehder]. A series of six single genes $(P m-1 \ldots 6)$ were described in muskmelon (Cucumis melo L. var. reticulatus), each either dominant or partially dominant (Kenigsbuch and Cohen, 1989, 1992). A multi-allelic single locus for powdery mildew resistance has been identified in squash (Cucurbita moschata Poir) (Adeniji and Coyne, 1983). Powdery mildew resistance in mungbean (Vigna radiata $\mathrm{L}$. Wilczek) is controlled by two dominant genes (Reddy et al., 1994). In contrast, Tiwari et al. (1997) described two single recessive genes for powdery mildew resistance in Canadian pea (Pisum sativum L.) cultivars.

Although the single gene for powdery mildew resistance will be relatively easy to introgress into new and existing cultivars, the longevity of this resistance remains to be determined, since breakdown of resistance conferred by single genes has been reported (Fischer et al., 1994; Kiyosawa, 1982; Parisi et al., 1993). Presence of the sexual stage and the rapid reproduction rate in the asexual cycle of $P$. clandestina may warrant identification and accumulation of additional sources of resistance. However, resistance of the original PMR-1 trees has shown no signs of breakdown during 22 years of evaluation in the IAREC experimental orchards.

\section{Literature Cited}

Adeniji, A.A. and D.P. Coyne. 1983. Genetics and nature of resistance to powdery mildew in crosses of Butternut with Calabaza squash and 'Seminole Pumpkin'. J. Amer. Soc. Hort. Sci. 108:360-368.

Dayton, D.F. 1977. Genetic immunity to apple mildew incited by Podosphaera leucotricha. HortScience 12:225-226.

Dirlewanger, E., T. Pascal, C. Zuger, and J. Kervella. 1996. Analysis of molecular markers associated with powdery mildew resistance genes in peach (Prunus persica (L.) Batsch) X Prunus davidiana hybrids. Theor. Appl. Genet. 93:909_ 919.

English, H. 1947. Powdery mildew on cherry fruit in Washington. Phytopathology 37:421-424.

Erickson, E.O. and W.F. Wilcox. 1997. Distributions of sensitivities to three sterol demethylation inhibitor fungicides among populations of Uncinula necator sensitive and resistant to triadimefon. Phytopathology 87:784-791.

Fischer, C., A. Bondarenko, and E. Artamonova. 1994. Results on the stability of scab resistance in apple breeding, p. 81-85. In: H. Schmidt and M. Kellerhals (eds.). Progress in temperate fruit breeding. Kluwer Academic, Boston.

Fogle, H.W. 1961. Inheritance of some fruit and tree characteristics in sweet cherry crosses. Proc. Amer. Soc. Hort. Sci. 78:76-85.

Fogle, H.W. 1975. Cherries, p. 348-366. In: J. Janick and J.N. Moore (eds.). Advances in fruit breeding. Purdue Univ. Press, West Lafayette, Ind.

Galletta, G.J. 1983. Pollen and seed management, p. 23-47. In: J.N. Moore and J. Janick (eds.). Methods in fruit breeding. Purdue Univ. Press, West Lafayette, Ind.

Gallott, J.C., R.C. Lamb, and H.S. Aldwinckle. 1985. Resistance to powdery mildew from some small-fruited Malus cultivars. HortScience
20:1085-1087.

Grove, G.G. 1991. Powdery mildew of sweet cherry: Influence of temperature and wetness duration on release and germination of ascospores of Podosphaera clandestina. Phytopathology 81:1271-1275.

Grove, G.G. 1997. New directions in controlling cherry powdery mildew. The Good Fruit Grower 48(5):27-32.

Grove, G.G. 1998. Meteorological factors affecting airborne conidia concentrations and the latent period of Podosphaera clandestina on sweet cherry. Plant Dis. 82:741-746.

Grove, G.G. and R.J. Boal. 1991a. Overwinter survival of Podosphaera clandestina in eastern Washington. Phytopathology 81:385-391.

Grove, G.G. and R.J. Boal. 1991b. Factors affecting germination of conidia of Podosphaera clandestina on leaves and fruit of sweet cherry. Phytopathology 81:1513-1518.

Gubler, W.D., H.L. Ypema, D.G. Ouimette, and L.J. Bettiga. 1996. Occurrence and development of resistance in Uncinula necator to triadimefon, myclobutanil, and fenarimol in California grapevines. Plant Dis. 80:902-909.

Hedrick, U.P. 1915. The cherries of New York. J.B. Lyon, Albany, N.Y.

Hesler, L.R. and H.H. Whetzel. 1937. Manual of fruit diseases. Macmillan, New York.

Janse, J., J.J. Verhaegh, and A.P.M. den Nijs. 1994. Early selection for partial resistance to powdery mildew, Podosphaera leucotricha (Ell. et Ev.) Salm., in apple progenies. Euphytica 77:7-9.

Kenigsbuch, D. and Y. Cohen. 1989. Independent inheritance of resistance to race 1 and race 2 of Sphaerotheca fuliginea in muskmelon. Plant Dis. 73:206-208.

Kenigsbuch, D. and Y. Cohen. 1992. Inheritance and allelism of genes for resistance to races 1 and 2 of Sphaerotheca fuliginea in muskmelon. Plant Dis. 76:626-629.

Kerr, E.A. 1963. Inheritance of crinkle, variegation, and albinism in sweet cherry. Can. J. Bot. 41:1395-1404

Kiyosawa, S. 1982. Genetics and epidemiological modeling of breakdown of plant disease resistance. Ann. Rev. Phytopathol. 20:93-117.

Korban, S.S. and D.F. Dayton. 1983. Evaluation of Malus germplasm for resistance to powdery mildew. HortScience 18:219-220.

Olmstead, J.W., G.G. Grove, and G.A. Lang. 2001. Assessment of severity of powdery mildew infection of sweet cherry leaves by digital image analysis. HortScience 36:107-111.

Olmstead, J.W., G.A. Lang, and G.G. Grove. 2000a. A leaf disk assay for screening sweet cherry genotypes for susceptibility to powdery mildew. HortScience 35:274-277.

Olmstead, J.W., D.R. Ophardt, and G.A. Lang. 2000b. Sweet cherry breeding at Washington State University. Acta Hort. 522:103-110. 
Parisi, L., Y. Lespinasse, J. Guillaumes, and J. Kruger. 1993. A new race of Venturia inaequalis virulent to apples with resistance due to the $V f$ gene. Phytopathology 83:533-537.

Poehlman, J.M. and D.A. Sleper. 1995. Breeding field crops. 4th ed. Iowa State Univ. Press, Ames.

Reddy, K.S., S.E. Pawar, and C.R. Bhatia. 1994. Inheritance of powdery mildew (Erysiphe polygoni DC) resistance in mungbean (Vigna radiata L. Wilczek). Theor. Appl. Genet. 88:945-948.

Steel, R.G.D. and J.H. Torrie. 1980. Principles and procedures of statistics: A biometrical approach. 2nd ed. McGraw Hill, New York.

Tehrani, G. and S.K. Brown. 1992. Pollen-incompatibility and self-fertility in sweet cherry. Plant Breeding Rev. 9:367-388.
Tiwari, K.R., G.A. Penner, and T.D. Warkentin. 1997. Inheritance of powdery mildew resistance in pea. Can. J. Plant Sci. 77:307-310.

Toyama, T.K. 1978. Inheritance of fruit color in the sweet cherry. HortScience 13:155-156.

Toyama, T.K., D.R. Ophardt, W.E. Howell, and G.G. Grove. 1993. New powdery mildew resistant sweet cherry. Fruit Var. J. 47:234235. 